Article

\title{
Investigation of the Long-Term Antibacterial Properties of Titanium by Two-Step Micro-Arc Oxidation Treatment
}

\author{
Harumi Tsutsumi $^{1, *}$, Yusuke Tsutsumi ${ }^{2, *(\mathbb{D})}$, Masaya Shimabukuro ${ }^{1,3} \mathbb{D}$, Tomoyo Manaka ${ }^{4}\left(\mathbb{D}\right.$, Peng Chen ${ }^{1}(\mathbb{D}$, \\ Maki Ashida ${ }^{1}$, Kunio Ishikawa ${ }^{3}$, Hideki Katayama ${ }^{2}$ and Takao Hanawa ${ }^{1,5}$ (D) \\ 1 Institute of Biomaterials and Bioengineering, Tokyo Medical and Dental University (TMDU), \\ 2-3-10 Kanda-Surugadai, Chiyoda, Tokyo 101-0062, Japan; shimabukuro@dent.kyushu-u.ac.jp (M.S.); \\ chen.met@tmd.ac.jp (P.C.); ashida.met@tmd.ac.jp (M.A.); hanawa.met@tmd.ac.jp (T.H.) \\ 2 Research Center for Structural Materials, National Institute for Materials Science (NIMS), 1-2-1 Sengen, \\ Ibaraki, Tsukuba 305-0047, Japan; KATAYAMA.Hideki@nims.go.jp \\ 3 Department of Biomaterials, Faculty of Dental Science, Kyushu University, 3-1-1 Maidashi, Higashi-ku, \\ Fukuoka 812-8582, Japan; ishikawa@dent.kyushu-u.ac.jp \\ 4 Graduate School of Medical and Dental Sciences, Tokyo Medical and Dental University (TMDU), \\ 1-5-45 Yushima, Bunkyo, Tokyo 113-8510, Japan; manaka.met@tmd.ac.jp \\ 5 Center for Advanced Medical Engineering Research and Development, Kobe University, \\ 1-5-1 Minatojimaminamimachi, Chuoku, Hyogo, Kobe 650-0047, Japan \\ * Correspondence: htsutsumi.met@tmd.ac.jp (H.T.); TSUTSUMI.Yusuke@nims.go.jp (Y.T.)
}

\section{check for}

updates

Citation: Tsutsumi, H.; Tsutsumi, Y.; Shimabukuro, M.; Manaka, T.; Chen,

P.; Ashida, M.; Ishikawa, K.;

Katayama, H.; Hanawa, T.

Investigation of the Long-Term

Antibacterial Properties of Titanium by Two-Step Micro-Arc Oxidation Treatment. Coatings 2021, 11, 798. https://doi.org/10.3390/ coatings 11070798

Academic Editor: Gabriela Ciobanu

Received: 8 June 2021

Accepted: 29 June 2021

Published: 1 July 2021

Publisher's Note: MDPI stays neutral with regard to jurisdictional claims in published maps and institutional affiliations.

Copyright: (c) 2021 by the authors. Licensee MDPI, Basel, Switzerland. This article is an open access article distributed under the terms and conditions of the Creative Commons Attribution (CC BY) license (https:// creativecommons.org/licenses/by/ $4.0 /)$.
Abstract: Recently, biofilm formation caused by bacterial adhesion and colonization has been recognized as the major cause of failure in orthopedic and dental implant surgeries. In this study, a customized micro-arc oxidation (MAO) treatment technique was developed to obtain desirable antibacterial properties on Ti surfaces. The two-step MAO treatment was applied in the fabrication of specimens with Ag and with/without $\mathrm{Zn}$ in their surface oxide layer. In order to simulate practical usage, surface analyses and immersion tests were performed to evaluate the incorporation of $\mathrm{Ag}$ and $\mathrm{Zn}$ into the resulting oxide layer and ion release behavior, respectively. Additionally, the antibacterial properties of the specimens after long-term immersion in physiological saline were evaluated using Gram-negative facultative anaerobic bacteria. The MAO-treated specimens containing Ag and Zn exhibited excellent antibacterial properties against Escherichia coli, which were sustained even after 6 months of immersion in physiological saline to simulate practical usage. Moreover, the Ag ions released from the surface oxide indicate the antibacterial properties of the specimen in the early stage, while the release of the corrosion products of $\mathrm{Zn}$ demonstrates its antibacterial properties in the later stage.

Keywords: titanium; antibacterial property; micro-arc oxidation; Escherichia coli; silver; zinc

\section{Introduction}

$\mathrm{Ti}$ and its alloys are widely used in medical fields, such as orthopedics and dentistry, due to their excellent mechanical properties and biocompatibility. In implant devices, $\mathrm{Ti}$ has been associated with strong and accelerated adhesion between the implant surface and surrounding bone, achieving a shorter healing period and immediate loading [1-4]. However, in recent years, the major cause of failure in orthopedic and dental implant surgeries has been determined to be biofilm formation due to bacterial adhesion and subsequent colonization on biomaterials [5-9]. Once a biofilm is formed and firmly adhered to the implant, bacterial secretion plays a pestiferous role as a barrier against the defense mechanisms of the host, resulting in difficulty eliminating pathogens during biofilm formation from implanted devices. Further, in serious cases, the only way to prevent subsequent infections and other undesirable biological reactions is to remove contaminated devices from the patient. 
The easiest strategy to prevent biofilm formation on metallic devices is polishing, as a rough surface promotes bacterial adhesion. In particular, the increase in surface area and formation of pockets increases bacterial presence $[10,11]$. However, for dental implants and orthodontic fixators in contact with bones, a rough surface is preferred to ensure hard-tissue compatibility; thus, surface polishing is not the most effective approach for this application. Another method to prevent biofilm formation is the application of antibacterial agents. Antibacterial properties are required for the biofunction of implant surfaces. Ag and Zn ions are known as reliable agents with superior antibacterial properties; thus, several studies have examined their effects against various bacteria [12-22]. Therefore, surface modification should enable the formation of a biofunctional layer that supports $\mathrm{Ag}$ and $\mathrm{Zn}$ ions to overcome problems associated with biofilms on metallic biomaterials.

Micro-arc oxidation (MAO) is a conventional wet-process surface treatment based on electrochemical reactions [23-26]. Under high voltage, anodic oxidation with microdischarges on the specimen surface forms a connective, porous oxide layer with elements incorporated from the electrolyte solution. For example, MAO using electrolytes comprising $\mathrm{Ca}$ and $\mathrm{P}$ ions improves the hard-tissue compatibility of Ti due to the spontaneous formation of calcium phosphate $[27,28]$. Therefore, MAO treatment can be utilized in incorporating the desired elements, which are dissolved in the electrolyte into the resulting oxide layer.

In our previous study, we reported the effectivity of $\mathrm{Ag}$ and $\mathrm{Zn}$ in inhibiting the proliferation of Escherichia coli (E. coli) and/or Staphylococcus aureus (S. aureus), respectively [29-32]. The results showed the different inhibition mechanisms and efficacies of the elements. Particularly, Ag exhibits a strong antibacterial effect during the initial period, and $\mathrm{Zn}$ exhibits a heightened antibacterial effect over time. Furthermore, we developed a two-step MAO treatment [33] that allows for the introduction of a high concentration of Ag into the Ti surface. The two-step MAO treatment also enabled the fabrication of a specimen containing both $\mathrm{Ag}$ and $\mathrm{Zn}$ in its surface oxide layer. After immersion for one month, the MAO-treated surfaces containing Ag with/without Zn maintained excellent antibacterial properties [33].

Implants, especially artificial joints, must exhibit a specific biofunction to ensure longterm antimicrobial resistance. Implants with long-term antibacterial activity are strongly desired to address the late-onset infection problems in artificial hip joints [34-36] that occur approximately three to eight weeks after surgery. Therefore, an ideal biomaterial surface should have an antibacterial activity that can prevent the initial stages of infection, such as bacterial adhesion, and inhibit bacterial growth at later stages.

The above-mentioned two-step MAO treatment that we proposed previously [33] has been demonstrated to be a promising tool for solving late-onset infection problems in implanted devices. However, it was not possible to clearly distinguish whether the strong antibacterial properties were derived from both $\mathrm{Zn}$ and $\mathrm{Ag}$ ions or from Ag ions alone. Furthermore, it is unclear for how long the antimicrobial activity will be maintained after a prolonged exposure of several months.

Therefore, the present study focused on incorporating antibacterial elements into a Ti surface through MAO treatment to develop novel antibacterial implants without harmful effects on osteogenic cells. Further, we analyzed the long-term behavior of Ag with/without a Zn-incorporated surface oxide layer produced by the two-step MAO treatment for preventing late-onset infections. Additionally, we investigated the time transient effect of the surface composition, metal-ion release and antibacterial activity of Ag and $\mathrm{Zn}$. Changes in the antibacterial activity of the specimens before and after immersion for 2, 3, and 6 months in physiological saline were evaluated by using the standard method, with E. coli as the typical Gram-negative facultative anaerobic bacteria. 


\section{Materials and Methods}

\subsection{Specimen Preparation}

Ti disks with diameters of $25 \mathrm{~mm}$ were fabricated by mechanically cutting rods of commercially pure grade $2 \mathrm{Ti}$. The surfaces of the disks were mechanically ground using $\# 150$, \#320, \#600, and \#800 grit $\mathrm{SiC}$ abrasive papers and subsequently ultrasonicated using acetone and isopropanol. The disks were then kept in an auto-dry desiccator until further use. The Ti disk was fixed onto a polytetrafluoroethylene holder with an O-ring. The area in contact with the electrolyte was $398 \mathrm{~mm}^{2}$ ( $22.5 \mathrm{~mm}$ in diameter). The details of the working electrode were adopted from a previous study [37]. A 304 stainless-steel plate was used as the counter electrode. For the MAO treatment, the base composition of the electrolyte was $100 \mathrm{mM}$ calcium glycerophosphate and $150 \mathrm{mM}$ calcium acetate. Silver nitrate $\left(\mathrm{AgNO}_{3}\right)$ and zinc chloride $\left(\mathrm{ZnCl}_{2}\right)$ were added to the base electrolyte. After pouring the electrolyte into the electrochemical cell, the electrodes were connected to a direct current (DC) power supply (PL-650-0.1, Matsusada Precision Inc., Shiga, Japan), and a positive voltage with a constant current density of $251 \mathrm{Am}^{-2}$ was applied for $10 \mathrm{~min}$. The majority of the Ti disk was MAO-treated with an annular untreated area of $0.5 \mathrm{~mm}$ from the edge.

The two-step MAO treatment was conducted as follows: MAO treatment was performed in the first electrolyte until a voltage of $380 \mathrm{~V}$ was obtained, after which the current application was discontinued and the first electrolyte was immediately replaced with the second electrolyte. The current was reapplied with an upper limit of $400 \mathrm{~V}$ for a total treatment time of $10 \mathrm{~min}$. The specimen prepared using the base electrolyte without Ag and $\mathrm{Zn}$ is referred to as "0AgZn." The specimen prepared using the combination of the first and second electrolytes containing $i \mathrm{mM} \mathrm{Zn}(i=0$ or 2$)$ and / or $j \mathrm{mM} \mathrm{Ag}(j=0-10)$, respectively, is referred to as " $\mathrm{Zn}-j \mathrm{Ag}$ ".

\subsection{Surface Characterization}

Surface characterization was performed on the MAO-treated area of the specimens. A scanning electron microscope with an energy dispersive X-ray spectrometer (SEM/EDS, S-3400NX, Hitachi High-Tech Corp., Tokyo, Japan) was used to observe the surface morphology and perform the elemental analysis of the specimens.

\subsection{Metal Ion Release Evaluation}

Metal ion release measurements were recorded for the entire specimen. Inductively coupled plasma mass spectrometry (ICP-MS, ELEMENT XR, Thermo Fisher Scientific, Tokyo, Japan) was used to investigate the amounts of released $\mathrm{Ag}$ and $\mathrm{Zn}$ ions. The MAO-treated specimens in the electrolytes with/without Ag and $\mathrm{Zn}$ were incubated in $5 \mathrm{~mL}$ physiological saline $(0.9 \% \mathrm{NaCl})$ under various treatment conditions. They were sealed in a polyethylene container to allow for the release of $\mathrm{Ag}$ and $\mathrm{Zn}$ ions from the surface of the specimen. Subsequently, they were maintained in a thermostatic chamber at $37^{\circ} \mathrm{C}$ with moderate shaking $(80-100 \mathrm{rpm})$. Every seventh day, the pooled solution was transferred into a fresh physiological saline. ICP-MS was used to measure the concentrations of $\mathrm{Ag}$ and $\mathrm{Zn}$ ions in the tested solutions collected at immersion periods of 2 months (53-60 days), 3 months (83-90 days), and 6 months (173-180 days). After the metal ion release evaluations of the specimens immersed for various durations, the specimens were used as aged specimens to compare their antibacterial properties with those of the as-prepared specimens.

\subsection{Evaluation of Antibacterial Properties}

Antibacterial property tests were conducted in accordance with the domestic [38] and international [39] standard methods JIS Z2801 [38] and ISO 22196:2007 [39], respectively. The proliferation of the anaerobic Gram-negative bacteria E. coli (NBRC3972, NITE, Tokyo, Japan) on the specimens was evaluated. E coli is frequently utilized as one of the most standardized and convenient testing bacteria for evaluating the antibacterial properties of biomaterials, although it is absent in the oral cavity environment. A suspension medium 
was prepared with the 500-fold dilution of the nutrient broth containing $3 \mathrm{gL}^{-1}$ meat extract, $10 \mathrm{gL}^{-1}$ peptone, and $5 \mathrm{gL}^{-1}$ sodium chloride. The $\mathrm{pH}$ of each suspension medium was adjusted to 6.8 or 7.2 using sodium hydroxide or hydrochloric acid. The bacteria were added to the suspension mediums to obtain $3.1 \times 10^{6}$ colony-forming units (CFU) per $\mathrm{mL}$. The bacterial suspension $(0.1 \mathrm{~mL})$ was then dropped onto a specimen, and a cover film was immediately placed. The specimens and cover films were incubated at $35^{\circ} \mathrm{C}$ for $24 \mathrm{~h}$. Thereafter, they were washed using $9.9 \mathrm{~mL}$ sterile physiological saline. The CFU of the living bacteria dispersed into the physiological saline was determined using the culture medium sheet for E. coli (JNC Corp., Tokyo, Japan).

\section{Results and Discussion}

Figure 1 shows the typical surface morphology of the untreated and MAO-treated as-prepared specimens observed using SEM. There are several interconnected pores on the MAO-treated specimens. In addition, there is no obvious difference in the pore size and number of pores among the specimens prepared under the various treatment conditions. Figure 2 shows the typical surface morphology of the untreated and MAO-treated specimens after immersion in physiological saline for 2 months. There are no changes in the surface morphology before and after immersion, confirming the non-existent or negligible dissolution of the porous oxide layer during immersion in physiological saline. Moreover, there are no remarkable differences in the pore size and quantity of the specimens before and after immersion.

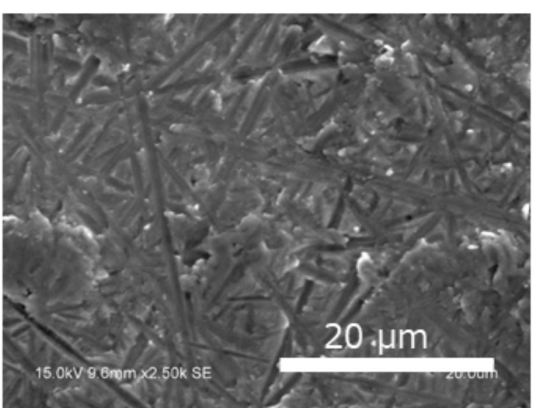

(a) Untreated

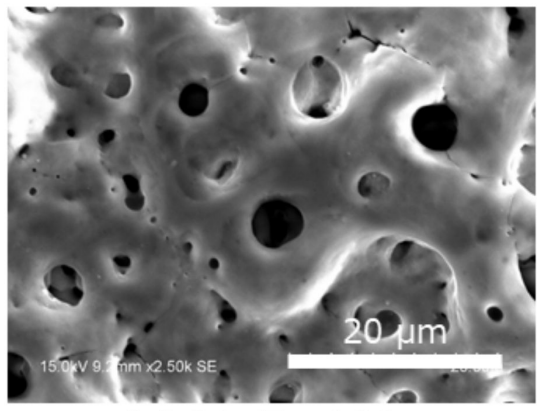

(c) $0 \mathrm{AgZn}-10 \mathrm{Ag}$

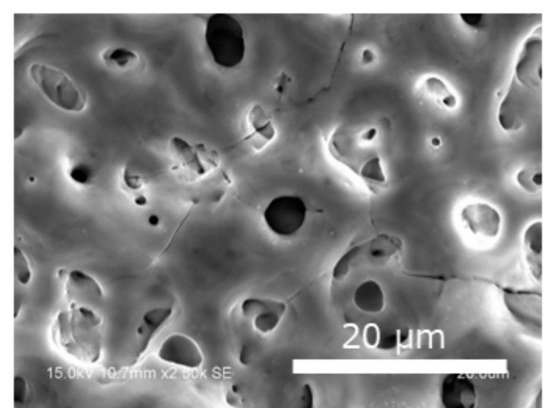

(b) OAgZn

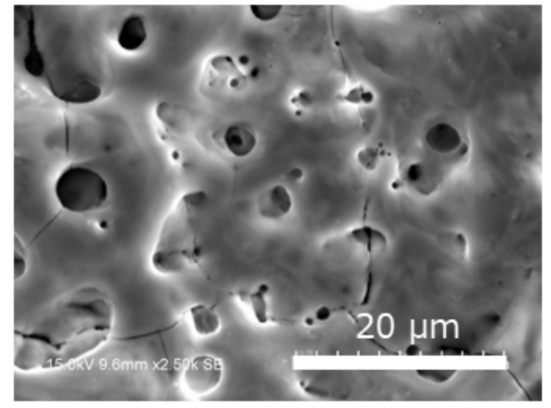

(d) $2 \mathrm{Zn}-10 \mathrm{Ag}$

Figure 1. Typical surface morphology of the as-prepared specimens: (a) untreated, (b) 0AgZn, (c) $0 \mathrm{AgZn}-10 \mathrm{Ag}$, and (d) $2 \mathrm{Zn}-10 \mathrm{Ag}$. 


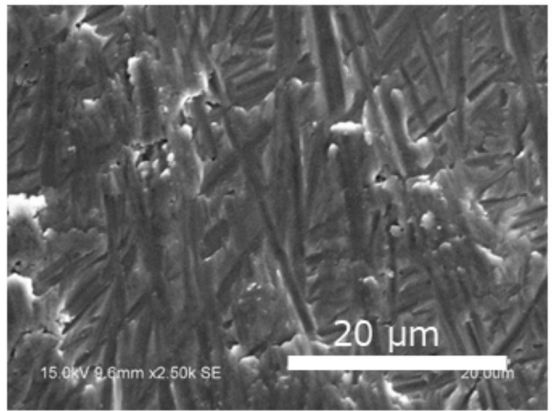

(a) Untreated

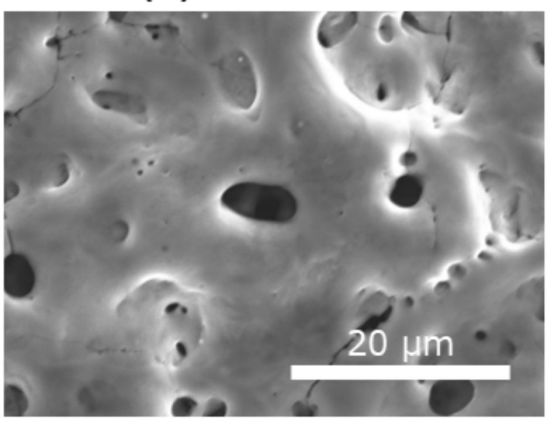

(c) $0 \mathrm{AgZn}-10 \mathrm{Ag}$

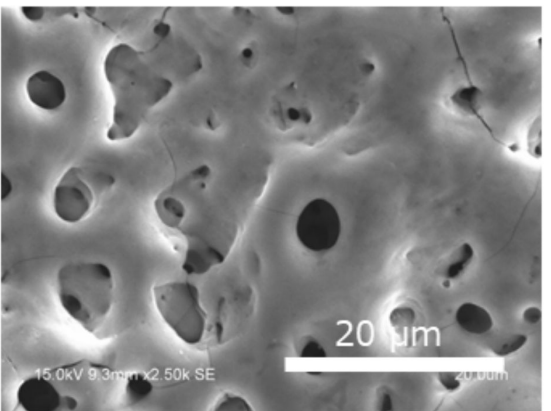

(b) 0AgZn

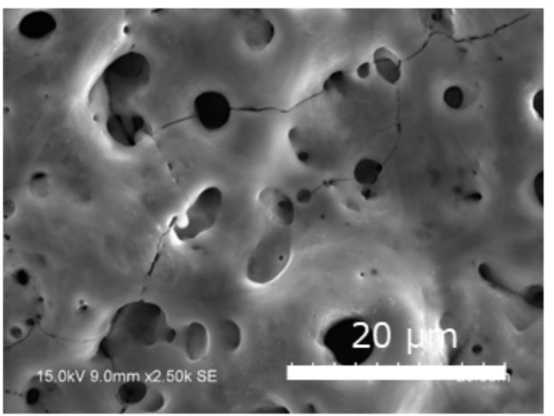

(d) $2 Z n-10 A g$

Figure 2. Typical surface morphology of the (a) untreated and MAO-treated (b) 0AgZn, (c) $0 \mathrm{AgZn}-10 \mathrm{Ag}$, and (d) $2 \mathrm{Zn}-10 \mathrm{Ag}$ specimens after immersion in physiological saline for 2 months.

EDS measurements were performed to evaluate the amounts of Ag (treatment condition is $0 \mathrm{AgZn}-x \mathrm{Ag}$ ) and $\mathrm{Ag}$ and $\mathrm{Zn}$ (treatment condition is $2 \mathrm{Zn}-x \mathrm{Ag}$ ) incorporated into the oxide layers through the two-step MAO treatment. Regardless of the treatment conditions, the chemical compositions of the layers were approximately constant at $28 \mathrm{wt} . \%$ Ti, 47 wt.\% O, 1 wt.\% C, 13 wt.\% Ca, and 11 wt.\% P (12 at.\% Ti, 57 at.\% O, 3 at.\% C, 9 at.\% $\mathrm{Ca}$, and 9 at.\% P). Therefore, a surface titanium oxide layer containing relatively large amounts of $\mathrm{Ca}$ and $\mathrm{P}$ is formed after MAO treatment.

The relationship between the $\mathrm{AgNO}_{3}$ concentration in the treatment electrolyte for the two-step treatment and the amount of $\mathrm{Ag}$ incorporated into the resulting surface oxide layer is shown in Figure 3a. For $0 \mathrm{AgZn}-x \mathrm{Ag}$, the amount of $\mathrm{Ag}$ in the oxide layer increased with an increase in the $\mathrm{AgNO}_{3}$ concentration in the second electrolyte. A similar trend was observed for $2 \mathrm{Zn}-x \mathrm{Ag}$, in which the amount of Ag incorporated into the oxide layer increased with an increase in the $\mathrm{AgNO}_{3}$ concentration in the second electrolyte. Therefore, regardless of the presence of $\mathrm{Zn}$, the amount of $\mathrm{Ag}$ increased with an increase in the $\mathrm{Ag}$ concentration in the electrolyte.

The two-step MAO treatment allowed for the use of solutions with high Ag content that exceed the concentration limit for the single-step treatments $(2.5-5 \mathrm{mM}[29,33])$. After the formation of the precursor oxide layer in the first step of the MAO treatment, the surface maintained a sufficiently high electrical resistance to maintain the MAO reaction. Figure $3 \mathrm{~b}$ shows the relationship between the $\mathrm{AgNO}_{3}$ concentration in the electrolyte solution for the two-step treatment and the amount of $\mathrm{Zn}$ incorporated into the resulting surface oxide layer. With the $\mathrm{ZnCl}_{2}$ concentration of the electrolyte fixed to $2 \mathrm{mM}$, there was almost no difference in the amount of $\mathrm{Zn}$ incorporated into the surface oxide layer. Meanwhile, the $\mathrm{AgNO}_{3}$ concentration in the second electrolyte had a minimal effect on the amount of $\mathrm{Zn}$ incorporated into the surface oxide surface. 
(a)

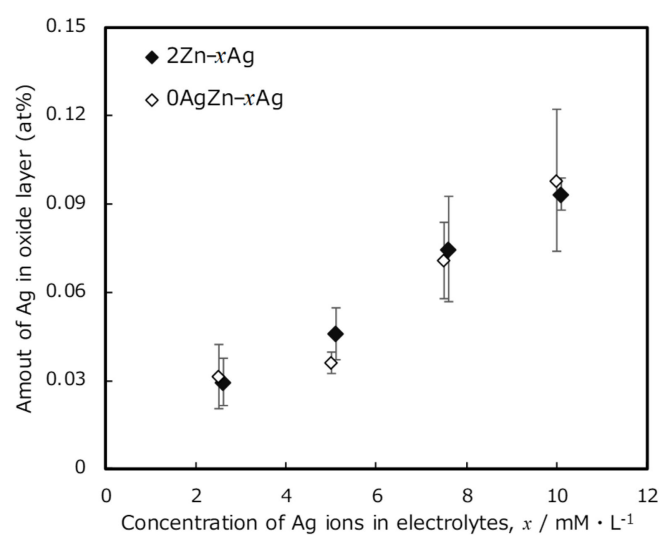

(b)

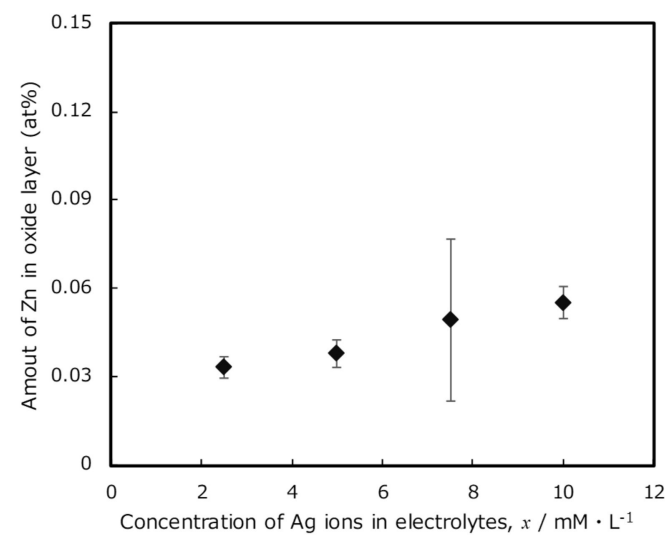

Figure 3. Relationship between the $\mathrm{AgNO}_{3}$ concentration in the second electrolyte and the amount of (a) $\mathrm{Ag}$ and (b) $\mathrm{Zn}$ incorporated into the resulting oxide layer.

Figure 4 shows the relationship between the $\mathrm{AgNO}_{3}$ concentration in the electrolyte and the amount of $\mathrm{Ag}$ in the oxide layer after immersion in physiological saline for 2 months. Comparing the specimens before (Figure 3a) and after (Figure 4) immersion in the saline solution, the amount of $\mathrm{Ag}$ in the oxide film decreased after immersion, especially in specimens with a higher $\mathrm{Ag}$ content. For $0 \mathrm{AgZn}-x \mathrm{Ag}$, a relatively higher amount of $\mathrm{Ag}$ was maintained in the surface oxide layer, even after 2 months of immersion, showing a similar trend to that of $0 \mathrm{AgZn}-x \mathrm{Ag}$ before immersion. For the $2 \mathrm{Zn}-x \mathrm{Ag}$ specimens, although $\mathrm{Ag}$ was detected in the surface oxide layer after 2 months of immersion, the amount of residual $\mathrm{Ag}$ with respect to the $\mathrm{Ag}$ concentration in the electrolyte did not exhibit a linearly increasing trend. Particularly, $2 \mathrm{Zn}-10 \mathrm{Ag}$ had a significantly lower Ag content than that of $0 \mathrm{AgZn}-10 \mathrm{Ag}$, which differed from the trend seen in $2 \mathrm{Zn}-x \mathrm{Ag}$ before immersion. In addition, after 2 months of immersion the amount of $\mathrm{Zn}$ in the surface oxide layer of all $2 \mathrm{Zn}-x \mathrm{Ag}$ specimens was under the detection limit of EDS. Moreover, the specific X-ray energy peak derived from $\mathrm{Zn}$ might overlap with that derived from $\mathrm{Na}$. Nevertheless, it could be considered that the $\mathrm{Zn}$ incorporated into the oxide layer was consumed to some extent during the immersion period in physiological saline. However, it was suggested that the presence of $\mathrm{Zn}$ in the oxide layer affects the release of the Ag ions from the surface oxide during immersion in physiological saline.

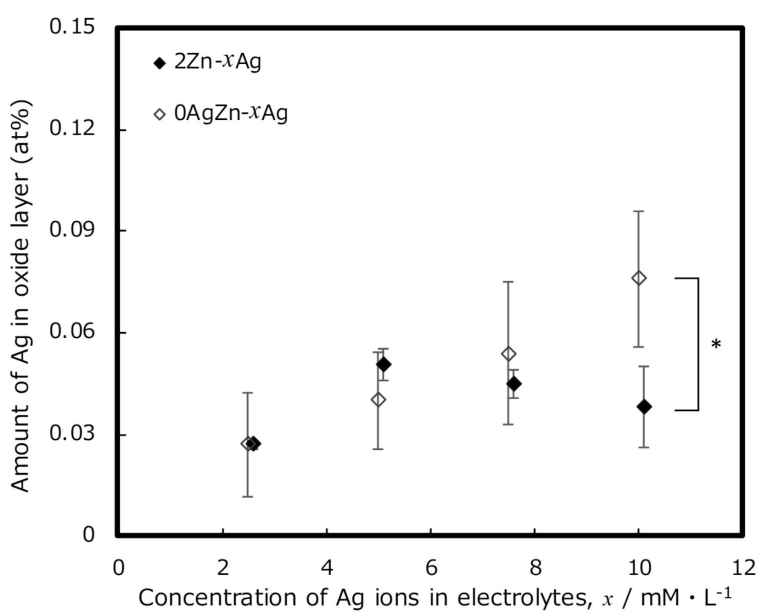

Figure 4. Relationship between the $\mathrm{AgNO}_{3}$ concentration in the second electrolyte and the amount of $\mathrm{Ag}$ incorporated into the resulting oxide layer after 2 months of immersion in physiological saline. (*: Statistically significant difference, $p<0.05)$. 
In order to elucidate the metal ion release behavior, long-term immersion tests were performed under specific specimen conditions following the same method as that described above. The amount of Ag ions released from the oxide layer into physiological saline, as determined by ICP-MS, is shown in Figure 5. The highest amount of Ag ions was released within the first 2 months of the measurement period, and the amount gradually decreased thereafter. Both $0 \mathrm{AgZn}-10 \mathrm{Ag}$ and $2 \mathrm{Zn}-10 \mathrm{Ag}$ demonstrated the suppressed release of $\mathrm{Ag}$ ions during the immersion period. After 2 months of immersion, the amount of Ag ions released from $2 \mathrm{Zn}-10 \mathrm{Ag}$ was slightly less than that released from $0 \mathrm{AgZn}-10 \mathrm{Ag}$. After 3 and 6 months of immersion, both specimens exhibited the same amount of Ag ion release. In our previous study [33], the highest amount of released Ag ions was noted in the surface oxide layer of MAO-treated Ti containing Ag during the first week of immersion in physiological saline, and the amount gradually decreased after immersion for one month. The results of the present study are consistent with this trend, indicating that the release of Ag ions degrades after a long period of usage.

(a)

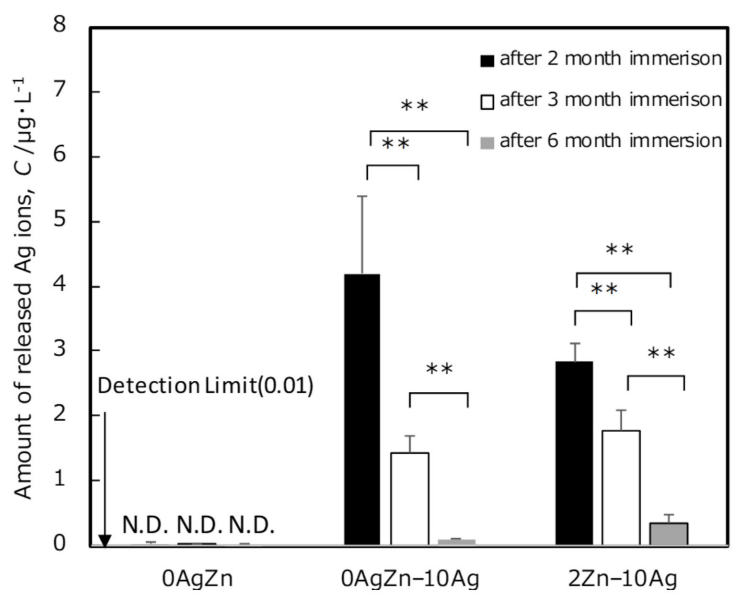

(b)

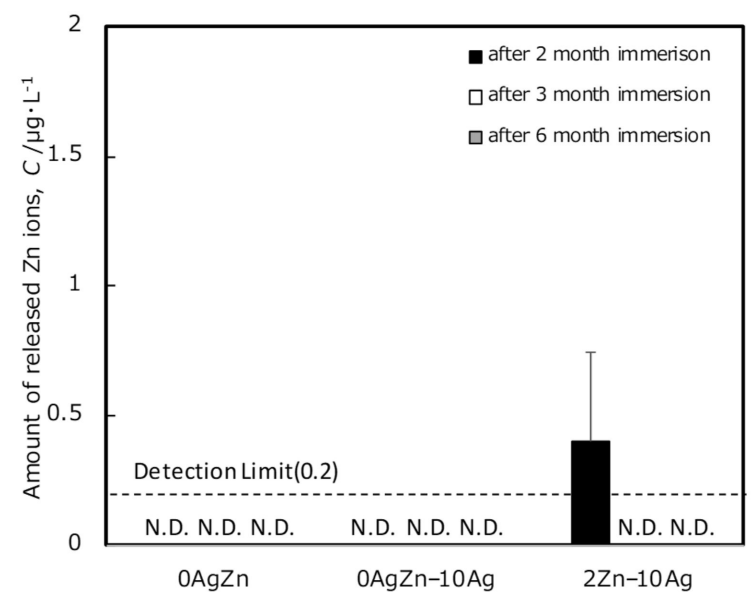

Figure 5. Amount of (a) Ag ions and (b) Zn ions released from the oxide layer into physiological saline. (N.D.: Not detected, **: Statistically significant difference, $p<0.05)$.

In our previous study [31,33], Zn ion release from specimens incorporated with $\mathrm{Zn}$ using MAO treatment could not be detected with ICP atomic emission spectroscopy. Therefore, ICP-MS, which has a 100-1000 times higher detection sensitivity, was employed to detect the trace amounts of released $\mathrm{Zn}$; however, the volume of $\mathrm{Zn}$ ions released from the oxide layer was still below the detection limit for all tested specimens. This can be attributed to the strong adsorption of $\mathrm{Zn}$ ions followed by the formation of $\mathrm{Zn}$ products and complexes on the surface [31]. The $\mathrm{Zn}$ ions released from the oxidized layer were immediately consumed for the reaction that formed the $\mathrm{Zn}$ species; thus, only minimal amounts of $\mathrm{Zn}$ were released into the solution.

Antibacterial tests were performed to investigate the antibacterial effects of the $\mathrm{Zn}$ products that gradually formed on the specimen's surface after its long-term immersion in a simulated body fluid. Figure 6 shows the change in the antibacterial properties of the MAO-treated and untreated Ti specimens against E. coli. After $24 \mathrm{~h}$ of culturing, almost all bacteria survived on the surface of the reference specimens that lacked antibacterial agents (i.e., untreated $\mathrm{Ti}$ and $0 \mathrm{AgZn}$ ). In contrast, $0 \mathrm{AgZn}-10 \mathrm{Ag}$ and $2 \mathrm{Zn}-10 \mathrm{Ag}$ exhibited strong antibacterial properties, as indicated by the complete absence of $E$. coli after $24 \mathrm{~h}$ of culturing. Further, this antimicrobial effect was maintained after specimens underwent 2 months of aging treatment by immersion in physiological saline solution. This superior antibacterial properties of the as-prepared fresh specimens against $E$. coli can be mainly attributed to the release of $\mathrm{Ag}$ ions, as shown in Figure $5 \mathrm{a}$. In the case of $0 \mathrm{AgZn}-10 \mathrm{Ag}$, the amount of Ag ions released continued to decrease during the immersion in physiological 
saline, in which it decreased by a factor of approximately 3 after 3 months and a factor of approximately 40 after 6 months. Therefore, in practical usage, the antibacterial properties of MAO-treated specimens are expected to weaken because of the decreasing Ag ion release that occurs during long-term implantation.

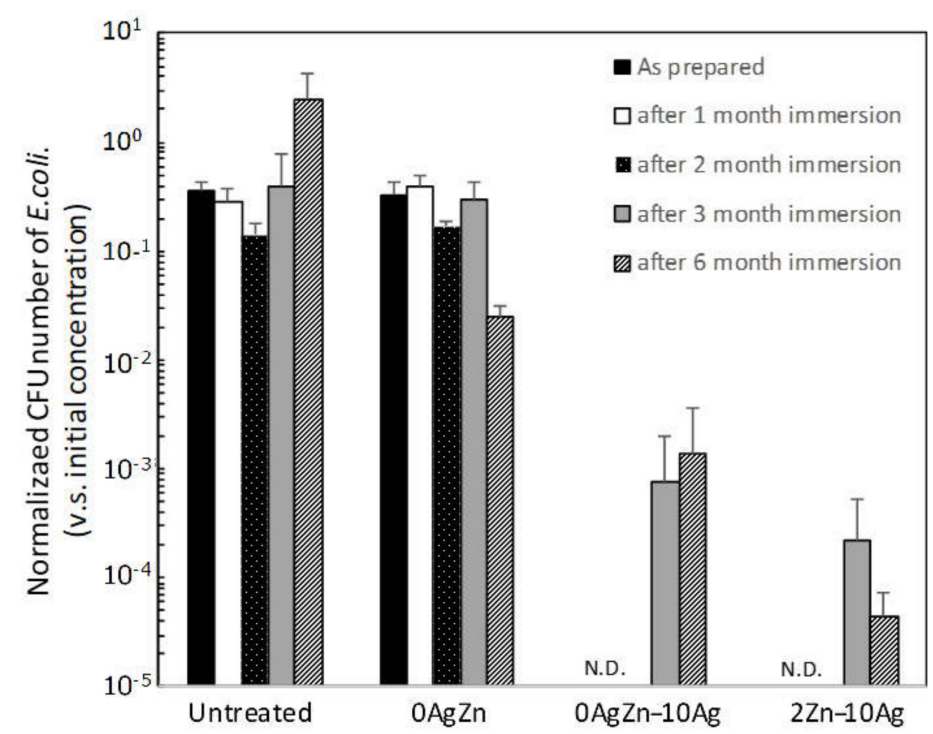

Figure 6. Changes in the antibacterial properties of the specimens against E. coli before and after immersion in physiological saline. (N.D.: Not detected).

As expected, antibacterial properties decreased as the immersion period increased from 2 to 6 months. This can be attributed to the depletion of the incorporated Ag ions and/or the formation of insoluble salts, such as $\mathrm{AgCl}$, which covered the surface because the amount of leached $\mathrm{Ag}$ ions decreased with the increasing immersion time. For $2 \mathrm{Zn}-10 \mathrm{Ag}$, the antibacterial effect decreased after 3 months of immersion and increased again after 6 months of immersion, which differs from ICP-MS measurement results, wherein the amount of released Ag ions decreased with the increasing immersion time. This suggests that the $\mathrm{Zn}$ products on the specimen surface gradually formed and matured during the immersion period [31]. Therefore, the prolonged antibacterial efficacy of the specimens could be attributed to the presence of $\mathrm{Zn}$. The re-emergence of the antibacterial properties of $2 \mathrm{Zn}-10 \mathrm{Ag}$ after 6 months of aging corresponds with the delayed effect noted in the single-step MAO treatment proposed in our previous study [29,31], in which complex Zn products were detected by X-ray photoelectron spectroscopy (XPS).Therefore, the two-step MAO treatment that introduced $\mathrm{Ag}$ and $\mathrm{Zn}$ into the Ti surface enabled two independent antibacterial effects: an initial antibacterial property due to the release of $\mathrm{Ag}$ ions and a delayed antibacterial property due to the formation of Zn products. Moreover, the excellent antibacterial properties of the MAO-treated Ti surface were maintained after 6 months of practical usage.

Finally, the limitations of this study must be mentioned. Under the set experimental conditions, Zn could not be directly detected by EDS after immersion in physiological saline. Moreover, under most conditions, the trace amounts of $\mathrm{Zn}$ ions released during the immersion were almost undetectable even with high-resolution ICP-MS measurement. As a subject for future research, $\mathrm{Zn}$ can be detected by examining the chemical surface state of the specimen surface through XPS. In addition, we plan to optimize treatment conditions, such as the amount of incorporated Ag and Zn, because excess Ag ion release has a cytotoxic effect on osteogenic cells [40-45]. Realizing both antibacterial properties and hard-tissue compatibility is the ideal outcome of this study [29]. Another limitation of the present study is the lack of results on the effectiveness of the proposed method against various bacterial species. Although E. coli is used in standard tests, the effect of $\mathrm{Ag}$ and $\mathrm{Zn}$ on other bacteria remains unknown, even with the broad antibacterial 
spectrum of Ag [13-15,46-49]. Particularly, Gram-positive facultative anaerobic bacteria, such as $S$. aureus, and primal bacteria play important roles in biofilm formation in practical environments; thus, they should be investigated in more detail.

\section{Conclusions}

$\mathrm{Ag}$ and $\mathrm{Zn}$ were successfully incorporated onto Ti surfaces using the proposed twostep MAO treatment. The excellent antibacterial properties of the resulting surfaces were sustained even after 6 months of immersion in physiological saline, which simulated the behavior of the specimens in an implanted environment. During the 6-month immersion of the specimens, the release of $\mathrm{Ag}$ ions from the surface oxide demonstrates the antibacterial properties of the specimens in the early stage, while the formation of $\mathrm{Zn}$ products demonstrates the antibacterial properties of the specimens in the later stage. In the future, the treatment conditions for incorporating Ag and $\mathrm{Zn}$ should be investigated to realize the desirable long-term bactericidal properties of surfaces after implant surgery.

Author Contributions: Conceptualization, H.T., Y.T. and T.H.; methodology, Y.T. and M.S.; validation, H.T.; formal analysis, H.T.; investigation, H.T., M.S. and T.M.; resources, H.K. and T.H.; data curation, P.C. and M.A.; writing—original draft preparation, H.T.; writing—review and editing, Y.T.; visualization, H.T. and Y.T.; supervision, Y.T.; project administration, Y.T., K.I., H.K. and T.H.; funding acquisition, Y.T., K.I., H.K. and T.H. All authors have read and agreed to the published version of the manuscript.

Funding: This research was partially funded by the JSPS Research Fellowship under grant number JP201940065 and the Research Center for Biomedical Engineering.

Institutional Review Board Statement: Not applicable.

Informed Consent Statement: Not applicable.

Data Availability Statement: Not applicable.

Conflicts of Interest: The authors declare no conflict of interest. The funders had no role in the design of the study; in the collection, analyses, or interpretation of data; in the writing of the manuscript; or in the decision to publish the results.

\section{References}

1. Zubery, Y.; Bichacho, N.; Moses, O.; Tal, H. Immediate loading of modular transitional implants: A histologic and histomorphometric study in dogs. Int. J. Periodontics Restor. Dent. 1999, 19, 343-353.

2. Hui, E.; Chow, J.; Li, D.; Liu, J.; Wat, P.; Law, H. Immediate provisional for single-tooth implant replacement with Brånemark system: Preliminary report. Clin. Implant Dent. Relat. Res. 2001, 3, 79-86. [CrossRef]

3. Cochran, D.L.; Buser, D.; Ten Bruggenkate, C.M.; Weingart, D.; Taylor, T.M.; Bernard, J.P.; Peters, F.; Simpson, J.M. The use of reduced healing times on ITI@implants with a sandblasted and acid-etched (SLA) surface: Early results from clinical trials on ITI@SLA implants. Clin. Oral Implant. Res. 2002, 13, 144-153. [CrossRef] [PubMed]

4. Lorenzoni, M.; Pertl, C.; Zhang, K.; Wimmer, G.; Wegscheider, W.A. Immediate loading of single-tooth implants in the anterior maxilla. Preliminary results after one year. Clin. Oral Implant. Res. 2003, 14, 180-187. [CrossRef] [PubMed]

5. Paquette, D.W.; Brodala, N.; Williams, R.C. Risk factors for endosseous dental implant failure. Dent. Clin. N. Am. 2006, 50, 361-374. [CrossRef]

6. Dibart, S.; Warbington, M.; Su, M.F.; Skobe, Z. In vitro evaluation of the implant-abutment bacterial seal: The locking taper system. Int. J. Oral Maxillofac. Implant. 2005, 20, 732-737.

7. Glauser, R.; Schupbach, P.; Gottlow, J.; Hammerle, C.H.F. Periimplant soft tissue barrier at experimental one-piece mini-implants with different surface topography in humans: A light-microscopic overview and histometric analysis. Clin. Implant Dent. Relat. Res. 2005, 7, s44-s51. [CrossRef] [PubMed]

8. Tesmer, M.; Wallet, S.; Koutouzis, T.; Lundgren, T. Bacterial colonization of the dental implant fixture-abutment interface: An in vitro study. J. Periodontol. 2009, 80, 1991-1997. [CrossRef] [PubMed]

9. MacKintosh, E.E.; Patel, J.D.; Marchant, R.E.; Anderson, J.M. Effects of biomaterial surface chemistry on the adhesion and biofilm formation of staphylococcus epidermidis in vitro. J. Biomed. Mater. Res. A 2006, 78, 836-842. [CrossRef] [PubMed]

10. Ono, M.; Nikaido, T.; Ikeda, M.; Imai, S.; Hanada, N.; Tagami, J.; Matin, K. Surface properties of resin composite materials relative to biofilm formation. Dent. Mater. J. 2007, 26, 613-622. [CrossRef] 
11. Meredith, D.O.; Eschbach, L.; Wood, M.A.; Riehle, M.O.; Curtis, A.S.G.; Richards, R.G. Human fibroblast reactions to standard and electropolished titanium and Ti-6Al-7Nb, and electropolished stainless steel. J. Biomed. Mater. Res. A 2005, 75, 541-555. [CrossRef]

12. Koerner, R.J.; Butterworth, L.A.; Mayer, I.V.; Dasbach, R.; Busscher, H.J. Bacterial adhesion to titanium-oxy-nitride (TiNOX) coatings with different resistivities: A novel approach for the development of biomaterials. Biomaterials 2002, 23, 2835-2840. [CrossRef]

13. Simonetti, N.; Simonetti, G.; Bougnol, F.; Scalzo, M. Electrochemical Ag ${ }^{+}$for preservative use. Appl. Environ. Microbiol. 1992, 58, 3834-3836. [CrossRef] [PubMed]

14. Wassall, M.A.; Santin, M.; Isalberti, C.; Cannas, M.; Denyer, S.P. Adhesion of bacteria to stainless steel and silver-coated orthopedic external fixation pins. J. Biomed. Mater. Res. 1997, 36, 325-330. [CrossRef]

15. Massè, A.; Bruno, A.; Bosetti, M.; Biasibetti, A.; Cannas, M.; Gallinaro, P. Prevention of pin track infection in external fixation with silver coated pins: Clinical and microbiological results. J. Biomed. Mater. Res. 2000, 53, 600-604. [CrossRef]

16. Samani, S.; Hossainalipour, S.M.; Tamizifar, M.; Rezaie, H.R. In vitro antibacterial evaluation of sol-gel-derived Zn-, Ag-, and $(\mathrm{Zn}+\mathrm{Ag})$-doped hydroxyapatite coatings against methicillin resistant Staphylococcus aureus. J. Biomed. Mater. Res. A 2013, 101, 222-230. [CrossRef] [PubMed]

17. Jin, G.; Qin, H.; Cao, H.; Qian, S.; Zhao, Y.; Peng, X.; Zhang, X.; Liu, X.; Chu, P.K. Synergistic effects of dual Zn/Ag ion implantation in osteogenic activity and antibacterial ability of titanium. Biomaterials 2014, 35, 7699-7713. [CrossRef]

18. Applerot, G.; Lipovsky, A.; Dror, R.; Perkas, N.; Nitzan, Y.; Lubart, R.; Gedanken, A. Enhanced antibacterial activity of nanocrystalline $\mathrm{ZnO}$ due to increased ROS-mediated cell injury. Adv. Funct. Mater. 2009, 19, 842-852. [CrossRef]

19. Storrie, H.; Stupp, S.I. Cellular response to zinc-containing organoapatite: An in vitro study of proliferation, alkaline phosphatase activity and biomineralization. Biomaterials 2005, 26, 5492-5499. [CrossRef]

20. Jones, N.; Ray, B.; Ranjit, K.T.; Manna, A.C. Antibacterial activity of ZnO nanoparticle suspensions on a broad spectrum of microorganisms. FEMS Microbiol. Lett. 2008, 279, 71-76. [CrossRef]

21. Dastjerdi, R.; Montazer, M. A review on the application of inorganic nano-structured materials in the modification of textiles: Focus on anti-microbial properties. Colloids Surf B Biointerfaces 2010, 79, 5-18. [CrossRef]

22. Raghupathi, K.R.; Koodali, R.T.; Manna, A.C. Size-dependent bacterial growth inhibition and mechanism of antibacterial activity of zinc oxide nanoparticles. Langmuir 2011, 27, 4020-4028. [CrossRef]

23. Suh, J.Y.; Jang, B.C.; Zhu, X.; Ong, J.L.; Kim, K. Effect of hydrothermally treated anodic oxide films on osteoblast attachment and proliferation. Biomaterials 2003, 24, 347-355. [CrossRef]

24. Son, W.W.; Zhu, X.; Shin, H.I.; Ong, J.L.; Kim, K.H. In vivo histological response to anodized and anodized/hydrothermally treated titanium implants. J. Biomed. Mater. Res. B Appl. Biomater. 2003, 66, 520-525. [CrossRef]

25. Kim, D.Y.; Kim, M.; Kim, H.E.; Koh, Y.H.; Kim, H.W.; Jang, J.H. Formation of hydroxyapatite within porous $\mathrm{TiO}_{2}$ layer by micro-arc oxidation coupled with electrophoretic deposition. Acta Biomater. 2009, 5, 2196-2205. [CrossRef]

26. Li, Y.; Lee, I.S.; Cui, F.Z.; Choi, S.H. The biocompatibility of nanostructured calcium phosphate coated on micro-arc oxidized titanium. Biomaterials 2008, 29, 2025-2032. [CrossRef] [PubMed]

27. Ha, J.Y.; Tsutsumi, Y.; Doi, Y.; Nomura, N.; Kim, K.H.; Hanawa, T. Enhancement of calcium phosphate formation on zirconium by micro-arc oxidation and chemical treatments. Surf. Coat. Technol. 2011, 205, 4948-4955. [CrossRef]

28. Song, W.H.; Ryu, H.S.; Hong, S.H. Antibacterial properties of Ag (or Pt)-containing calcium phosphate coatings formed by micro-arc oxidation. J. Biomed. Mater. Res. A 2009, 88, 246-254. [CrossRef]

29. Shimabukuro, M.; Tsutsumi, Y.; Yamada, R.; Ashida, M.; Chen, P.; Doi, H.; Nozaki, K.; Nagai, A.; Hanawa, T. Investigation of realizing both antibacterial property and osteogenic cell compatibility on titanium surface by simple electrochemical treatment ACS Biomater. Sci. Eng. 2019, 5, 5623-5630. [CrossRef] [PubMed]

30. Shimabukuro, M. Antibacterial property and biocompatibility of silver, copper, and zinc in titanium dioxide layers incorporated by one-step micro-arc oxidation: A review. Antibiotics 2020, 9, 716. [CrossRef] [PubMed]

31. Shimabukuro, M.; Tsutsumi, Y.; Nozaki, K.; Chen, P.; Yamada, R.; Ashida, M.; Doi, H.; Nagai, A.; Hanawa, T. Chemical and biological roles of zinc in a porous titanium dioxide layer formed by micro-arc oxidation. Coatings 2019, 9, 705. [CrossRef]

32. Shimabukuro, M.; Hiji, A.; Manaka, T.; Nozaki, K.; Chen, P.; Ashida, M.; Tsutsumi, Y.; Nagai, A.; Hanawa, T. Time-transient effects of silver and copper in the porous titanium dioxide layer on antibacterial properties. J. Funct. Biomater. 2020, 11, 44. [CrossRef]

33. Shimabukuro, M.; Tsutsumi, H.; Tsutsumi, Y.; Manaka, T.; Chen, P.; Ashida, M.; Ishikawa, K.; Katayama, H.; Hanawa, T. Enhancement of antibacterial property of titanium by two-step micro arc oxidation treatment. Dent. Mater. J. 2021, 40, 592-598.

34. Coventry, M.B. Treatment of infections occurring in total hip surgery. Orthop. Clin. N. Am. 1975, 6, 991-1003. [CrossRef]

35. Rees, R.T. Infections associated with dental procedures in total hip arthroplasty. J. Bone Jt. Surg. Br. 2000, 82, 307. [CrossRef]

36. Rubin, R.; Salvati, E.A.; Lewis, R. Infected total hip replacement after dental procedures. Oral. Surg. Oral Med. Oral Pathol. 1976, 41, 18-23. [CrossRef]

37. Tanaka, Y.; Kobayashi, E.; Hiromoto, S.; Asami, K.; Imai, H.; Hanawa, T. Calcium phosphate formation on titanium by low voltage electrolytic treatments. J. Mater. Sci. Mater. Med. 2007, 18, 797-806. [CrossRef] [PubMed]

38. JIS Z 2801:2012 Antimicrobial Products-Test for Antimicrobial Activity and Efficacy; Japanese Standards Association: Tokyo, Japan. 2012. Available online: https:/ / www.jisc.go.jp/eng/index.html (accessed on 30 June 2021). 
39. ISO 22196:2011 Plastics-Measurement of Antibacterial Activity on Plastics Surfaces; International Organization of Standardization: Geneva, Switzerland. 2011. Available online: https://www.iso.org/standard/54431.html (accessed on 30 June 2021).

40. Odnevall Wallinder, I.; Leygraf, C. A critical review on corrosion and runoff from zinc and zinc-based alloys in atmospheric environments. Corrosion 2017, 73, 1016-1077. [CrossRef]

41. Poon, V.K.M.; Burd, A. In vitro cytotoxicity of silver: Implication for clinical wound care. Burns. 2004, 30, 140-147. [CrossRef]

42. Wataha, J.C.; Lockwood, P.E.; Schedle, A. Effect of silver, copper, mercury, and nickel ions on cellular proliferation during extended, low-dose exposures. J. Biomed. Mater. Res. 2000, 52, 360-364. [CrossRef]

43. Yamamoto, A.; Honma, R.; Sumita, M. Cytotoxicity evaluation of 43 metal salts using murine fibroblasts and osteoblastic cells. J. Biomed. Mater. Res. 1998, 39, 331-340. [CrossRef]

44. AshaRani, P.V.; Mun, G.L.K.; Hande, M.P.; Valiyaveettil, S. Cytotoxicity and genotoxicity of silver nanoparticles in human cells. ACS Nano. 2009, 3, 279-290. [CrossRef]

45. Rosário, F.; Hoet, P.; Santos, C.; Oliveira, H. Death and cell cycle progression are differently conditioned by the AgNP size in osteoblast-like cells. Toxicology 2016, 368-369, 103-115. [CrossRef]

46. Contreras, R.G.; Vilchis, J.R.S.; Sakagami, H.; Nakamura, Y.; Nakamura, Y.; Hibino, Y.; Nakajima, H.; Shimada, J. Type of cell death induced by seven metals in cultured mouse osteoblastic cells. In Vivo 2010, 24, 507-512. [PubMed]

47. Shao, W.; Liu, X.; Min, H.; Dong, G.; Feng, Q.; Zuo, S. Preparation, characterization, and antibacterial activity of silver nanoparticledecorated graphene oxide nanocomposite. ACS Appl. Mater. Interfaces 2015, 7, 6966-6973. [CrossRef]

48. Jia, Z.; Xiu, P.; Li, M.; Xu, X.; Shi, Y.; Cheng, Y.; Wei, S.; Zheng, Y.; Xi, T.; Cai, H.; et al. Bioinspired anchoring AgNPs onto micro-nanoporous $\mathrm{TiO}_{2}$ orthopedic coatings: Trap-killing of bacteria, surface-regulated osteoblast functions and host responses. Biomaterials 2016, 75, 203-222. [CrossRef] [PubMed]

49. De Faria, A.F.; Perreault, F.; Shaulsky, E.; Arias Chavez, L.H.; Elimelech, M. Antimicrobial electrospun biopolymer nanofiber mats functionalized with graphene oxide-silver nanocomposites. ACS Appl. Mater. Interfaces 2015, 7, 12751-12759. [CrossRef] [PubMed] 